\title{
FOSTERING SPIRITUAL AND MORAL VALUES IN CHILDREN IN CONTEMPORARY CHUVASH FAMILIES
}

\author{
Klara V. Pushkina ${ }^{1 \star}$, Aleksey A. Pushkin ${ }^{2}$ \\ ${ }^{1}$ Assoc. Prof., Chuvash State University, RUSSIA, klara-608389@mail.ru \\ ${ }^{2}$ Assoc. Prof., Chuvash State University, RUSSIA, fldh@mail.ru \\ ${ }^{*}$ Corresponding Author
}

\begin{abstract}
The Chuvash people have a very ancient history and unique culture. At all times the concept of family has occupied the leading position in the hierarchy of spiritual and moral values of the Chuvash people and served as a token for expressing these values. The prominent Chuvash enlightener Ivan Yakovlev appealing to all his kinsmen through his famous testament urged to remember that family was a sacred pillar on which the well-being of each family rests. Having been under the yoke of Russian tsarism for many centuries common Chuvash people were well aware of the fact that they might survive only thanks to a united and close-knit family. The illiterate grand-parents and parents had to instill the ideas of unity, respect for their parents, elderly people, perseverance, adherence to family traditions in their kids. Goal oriented practical activities of the children under the common sense supervision of their parents and the elderly were actually underlying the fundamentals of family pedagogy that was recognized as such after many years to come. In the second half of the twentieth century the world famous Chuvash educationist G. N. Volkov developed the ideas of family upbringing and education in Chuvash families in his Chuvash ethnic pedagogy. In his opinion family traditions and values that are tested and honored throughout centuries still remain important for the Chuvash people although spiritual and moral values which are instilled and developed in the younger generation are considered in modern ever so fast changing political, socio-economic, scientific and cultural environment.

The modern Chuvash families differ significantly from those of the past. These are not so much as economic conditions of families but psychological parameters that determine the emotional and socio-psychological well-being of families. Our research shows that the attachment of children to their parents is getting loose and worse. Influenced by a number of social circumstances the children seem to be alienating from their parents that cannot but worry the latter. In our opinion the parents only see what is above and fail to see what is under the iceberg. The failure to understand their children's behavior is accounted for by the following reasons: 1 ) the lack of fundamentals of pedagogical knowledge and skills of parents; 2) consigning by the parents to oblivion the fundamentals of Chuvash family education principles based on spiritual and moral values in fostering their children. We argue that studying the fundamentals of general pedagogy in combination with appealing to the heritage of ethnic pedagogy by the parents will yield positive results in upbringing and educating children. To meet these ends special educational techniques and methods are proposed.
\end{abstract}

Keywords: educational traditions, spiritual and moral values, modern Chuvash family, parents, children, older generations, ethnic pedagogy, personality formation, proverbs and sayings.

\section{INTRODUCTION}

The National Doctrine of Education of the Russian Federation aims at ensuring the historical continuity of 
generations, the preservation, dissemination and development of national culture, the upbringing of citizens of a legal, democratic state in the spirit of true patriotism, high morality and respect for the rights and freedoms of any individual. Hence, in this respect the main tasks of education for the nearest future are defined within the framework of a new paradigm, the major items of which being preservation and support of the ethnic identity of Russia as well as the humanistic traditions of its culture, the integration of the Russian education system into the world educational system whereby taking into account domestic experience and traditions. Man as a unique self sufficient entity developing his natural and social potentials on genetic and historical basis boosted by his social experiences of ethnic cultural traditions is a pivot of the educational process. For the formation of a personality a special social environment organized by adults is extremely important, i.e. a family in which national pedagogical traditions have a decisive educational value. Traditionally, any family regardless of ethnicity acts as a caretaker and translator of such moral values as: honor, friendship, work, love, intelligence, health, etc. The issues of upbringing of children on the basis of moral values and family traditions of peoples of Russia are considered in the historical and pedagogical researches done by G.N. Volkov (G. Volkov, 1958), T.N. Petrova (T. Petrova, 1996), E. I. Sokol'nikova (E. Sokol'nikova, 1997).

The Chuvash scientists N. I. Ashmarin (N. Ashmarin, 1928-1950), V. F. Kakhovsky (V. Kakhovsky, 1965), V. K. Magnitskij (1892), N. V. Nikolskij, (N. Nikolskij, 1919), A.G. Salmin (A, Salmin, 1994) did in-depth studies of the material and spiritual culture of the Chuvash people. They determined the role and significance of ethnic values in the process of parenting and educating kids, the ethnic values being considered as ethnicity forming and ethnicity preserving ones.

Although these ethnic values are based on common human morality concepts, large and by they are viewed through the prism of ethnicity and ethnic identity. In traditional Chuvash families such notions as generation gap, gender relations and social etiquette have always been exposed to ethnic state of mind and ethnic culture peculiarities. The same holds true concerning universal concepts as Motherland, family, honor, work, friendship, mutual assistance that are instilled in kids since early years. It is believed that it is thanks to ethnic traditions that multinational Russia was able to withstand troubles and wars in hard times.

The spiritual and moral development is the main task of parenting and educating kids. By spiritual and moral education we understand the process of purposeful assistance to instilling in kids the spiritual and moral values, which underlie basic culture of any individual. The spiritual and moral values component of upbringing kids in this respect consists in helping the latter to master the system of values and ideals leading to the formation of a certain personal worldview stance. At the same time the worldview stance of a kid is reflected by and in his being involved in social activity wherein he uncovers his feelings, attitudes and behavior.

It is common knowledge that the ethnic culture underlying spiritual and moral parenting and education of kids is mostly determined by the social environment that impacts their formation and development. It is the spiritual culture of the family that counts first. This is the spirit reigning in families and kindergartens, high schools and out of school units for kids. This is the spirit descending from parents and teachers, whom is a basic social environment of kids is composed of. It is this basic social environment that determines the formation of kid's inner world.

We argue that spiritual and moral education should be considered as the development of basic abilities of kids inherent to a human, and namely moral, aesthetic, religious abilities. Moral abilities urge kids to distinguish between good and evil. Aesthetic abilities help make the right choice between the beautiful and the ugly. Religious abilities are aimed at distinguishing between the moral and immoral. The development of these abilities has been looked upon as of paramount importance in Chuvash family parenting and education. The adult members of modern Chuvash families reared and educated on the afore mentioned sacred family traditions firmly believe that those principles of parenting and family education help reduce negative effects of generation gaps problems putting both the adults and the kids on the right track so that the latter learn to get along with the former, thus fostering in the kids the ability to live in community showing respect for adults and care for toddlers. These principles of parenting and education in the Chuvash ethnic families have become part and parcel of the traditional Chuvash ethnic family culture.

The spiritual family unity underlies the provisions for the spiritual and moral parenting and the education of kids. It is the best family traditions accumulated throughout the centuries that claim for spiritual and moral reviving of Russia.

The purpose of the study is to identify and scientifically substantiate the pedagogical conditions for the spiritual and moral education of kids on traditional family values. 
Thus, the underlying tasks are as following:

- Revealing the peculiarities of the spiritual and moral education of kids in the Chuvash family,

- Determining the moral potential of the traditional family values of the Chuvash,

- Substantiating the ethno-pedagogical dialogue cult in traditional family education among the Chuvash as a means of spiritual and moral education.

\section{METHODOLOGY}

The following research methods are applied: 1) general theoretical methods comprising the analysis of psychological and pedagogical literature on the subject matter under the review including encyclopaedic and reference literature, special archive records and folklore works, and 2) empirical methods including that of pedagogical observation, using questionnaires and surveys, generalization of ethno-pedagogical experience of educationists.

\section{OPINIONS AND DISCUSSION}

The problems of family education have always aroused wide public interest. The family, like society, is constantly evolving. The functions of the family also develop in accordance with the needs of society. Hence there is a great interest in the peculiarities of the educational function of the family in modern conditions.

Even the ancient Greek philosopher Plato believed that all the evil in the world comes mainly from the presence of unequal conditions of upbringing in families, that the blind love of parents for a child breeds individualism, greed and other vices. The upbringing influence of the family affects not only children, but also adults. A person is connected with the family and is exposed to it from the day of birth until the end of his life. At the same time, the influence of the family on the child determines the originality of the process of family education.

The conscious and purposeful pedagogical activity of parents is combined with the daily and very strong influence of the way of life of the family on the children. The role of personal example and authority of father and mother, kindred feelings, emotionality of the relationship of educators, which cannot be achieved outside the family, is great. With the birth of a child, a personality is not yet born; personality is formed only in the human environment. And the closest environment of a newborn is a family: mother, father, grandmother, grandfather, brothers, sisters, relatives. This means that parents and close relatives play a decisive role in ensuring that the newborn develops as a person and in the future becomes a subject, a master of his own development, i.e. personality.

The nature of intra-family relations has a very strong influence on the development of the individual. The most fruitful for this are such intra-family relationships, which are characterized by mutual care, an atmosphere of cordiality and human closeness. Closeness with parents and elders means for children such a relationship in which an adult gives the child the most intimate riches of his soul, gives disinterestedly, without demanding anything in return, and the child, absorbing all the best, in turn enriches the adult with the healing purity of his emotions, reveals to him the ingenuous secret places of his soul. That is why children feel an urgent need for friendly intra-family relationships, for good paternal and maternal influence, for being understood in the family.

It is good intra-family relations that have a positive impact on the comprehensive formation of the personality. Family traditions cement these relationships and strengthen their influence on children. Many traditions, becoming improved in the course of time, turn into rules, norms, a kind of unwritten laws of society.

Good traditions consolidate the family. The traditions work for preserving those seeds of reason and kindness that were found earlier by the older members of the family, thus turning into the property of the younger generations. The educational power of traditions lies primarily in the fact that the experience contained in them is perceived by the younger generation directly, naturally. The transfer of experience, work and everyday skills, the assimilation of cultural, moral and social values occurs through communication.

The formation of personality takes place in communication: a person learns to evaluate actions and relationships, learns moral norms, applies them in practice, observes the relationships of other people and builds their own. Such most important personality traits as responsibility, duty, adherence to principles, responsiveness, honesty, kindness are not only manifested, but also formed in communication.

Of all types of communication interpersonal one is of the greatest interest as it is based on direct human-tohuman communication. 
Interpersonal relationships are precisely those relationships that develop in real life between thinking and feeling people. Interpersonal relationships are the essence of communication, a kind of its result. Having arisen in the process of communication, interpersonal relationships, in turn, influence the communication itself, determining its content.

Communication contributes to the upbringing, first of all, of the younger generation. Children are the main moral value of the family. This situation is reinforced by the following arguments: the appearance of a child in the family makes the husband and wife close people, strengthens the feeling of the spouses with a new bond - parental love; the appearance of a child gives parents a new impulse to self-education, constant work on themselves; children in a family, according to the Chuvash, is the immortality of parents. Many other peoples were of the same opinion. It is children who teach adults lessons of altruism the essence of which is sacrificing for others. Children improve their parents, educate them, urge them to be better. In good, happy families children take care of their parents as parents do of their children. In such families children are trained to think about other people, not just about themselves.

The Chuvash scientist Ella Sokol'nikova who devoted her fundamental research work to an in-depth ethnopedagogical study of the Chuvash family in the historical perspective comes to the conclusion that "the Chuvash used to determine the moral image and character of young people by their attitude towards the adults. When someone happened to come to the house for the first time, he/she would judge about the human qualities of kids by the way the latter met him/her. Anyone who sincerely loved children was not capable of meanness and cruelty, as well as of lies and hypocrisy. That seemed like the obvious truth. To earn the favor of kids, adults had to somehow prove themselves as considerate and fair. The usual manifestations of a good attitude towards kids were welcoming the kid, inventing fun for him, teaching him to play and participating in his games, treating him with something delicious, etc. The utterance "Kids love him/her" served as the highest assessment of a person's spiritual kindness. The ability to establish sincere contacts with the underage, to tune up with their state of mind was highly appreciated by the Chuvash"(Sokol'nikova, 1997, p.135).

The birth of a child in a family has always been a great event, a sacred holiday for all relatives of the spouses.

The Chuvash have insisted that every family should have children, the more the better. At the wedding the newlyweds are given a kind of order Ikkĕn vyrtsa viççĕn tămalla pultăr - Two lie down together and three get up together. The newlyweds were charged with the obligation to be fertile and multiply. It is not accidental that in the wedding songs the newlyweds usually got the blessing Sak tulli acha-păcha pultăr May you have children full of bunks. The Chuvash compared childlessness with blindness. There is the Chuvash proverb saying Achasăr - kuçsăr - No children - no eyes.

Children strengthen the family. They decorate life and give joy, continue the human race and carry the baton on from generation to generation. "Affectionate child is like a happy age", "There is no death without a cause as there is no happiness without a child" , "The child is the support of the family, the future worker, the defender of the native land", "Only those who have children can count on a quiet old age as without children, it's quiet, but it's dashing for old age" - these are very typical Chuvash folk sayings that are taken for granted as a model for upbringing kids in the family

The responsibility of parents in raising their children is very often noted in the works of oral folk art of the Chuvash. A lot has been said about the role of parents in the formation of children in fairy tales, proverbs and sayings, and popular folk songs. Parents pass on their life, work, spiritual and moral experience to their children. The power of the educational influence of parents on their children is emphasized in the proverbs and sayings as in Amăshne păh ta hĕrne il' - If you want to marry a girl, study your future mother-in-law first, and Yvălĕsem ashĕne hună - The sons have taken after father.

Folk pedagogy prioritizes a mother's role in the upbringing of children. Ella Sokol'nikova notes in her monograph that "a Chuvash female in a family is a bonding outset as she completely determines the general spiritual and moral mood of the family" (Sokol'nikova, 1997, p. 75).

A mother is the one and only person whose love for children is noble, generous. She is full of wisdom and courage, and ready to sacrifice for her children's lives.

The special position of the mother in upbringing is explained by the difficulties of caring for young children, the important role of the mother's school in the formation of the younger generation.

The exceptional role of the mother in the upbringing of children of both sexes is well characterized in the Chuvash proverbs and sayings collected by N. Ashmarin, Russian linguist and ethnographer of the Chuvash 
colloquial speech, for his 17 volume Thesaurus of the Chuvash language" (Ashmarin, 1928-1950). These proverbs are passed on from generation to generation preserving the quintessence of the Chuvash ethnic ideas of parenting, e.g. Amăshĕ mattur pulsan, ashĕ uteriyeh pulmasan ta achisem ănaççĕ - If the mother is a strong person, then children grow up to be good people even when the father is not particularly good. One cannot but pay attention to the following Chuvash "hop" riddle and its interpretation, i.e. Ashĕ - tÿrĕ, amăshĕ - kukăr, hĕr - nachar, yvăl - usal (Ashmarin, 1928-1950, p.308), Father is straight, mother is crooked, daughter is bad, son is evil. In the riddle there is an allusion to the decisive role of the mother in the formation of the characters of both the daughter and the son. If the mother is crooked, it is difficult to expect any good from both children, for the daughter might be bad, and the son might be evil. The hop grows up wrapping around the pole. Although the pole symbolizes the leading role of fathers in the family life, the final result of upbringing is still determined by mothers. This idea is highlighted in the proverbs Atte nacharri inkek, anne nacharri vilĕm - Father's being bad is a trouble whereas mother's being bad is death, Ashĕ vilny - çur tălăh: amăshĕ vilni - pĕr tălăh - Father died - half-orphan, mother died - complete orphan, Ashĕ - allă, amăshĕ - pĕrre anchah - Fathers - fifty, and mother - only one (Ashmarin, 1928-1950, p.308).

The Chuvash people also emphasized the parental gender role in raising children. This thought is reflected in the proverb Arçyn acha ashshĕ çumne çypăçat', hĕracha - amăshĕ çumne - The son clings to the father, whereas the daughter clings to the mother (Ashmarin, 1928-1950, p. 246),

Patriarch of the Chuvash people I. Yakovlev, appreciating the great role of mothers in raising children, wrote that women create an elusive atmosphere of feelings that the younger generation breathes. In his opinion, the tribal dialect and tribal characteristics of aliens, i.e. ethnic minorities, are predominantly preserved and supported by their mothers (Yakovlev, 1982: 187). Justifying this position, he pointed out that Chuvash women firmly adhere to old customs and concepts. The founder of Chuvash pedagogy was right when he assigned mothers a special role in preserving the national identity of the Chuvash people.

At present it is very important for Chuvash women to realize their historical mission in the implementation of national goals of education, in preserving customs, traditions, language, i.e. mother tongue, costumes and in passing them on to the younger generation.

In the family, it is necessary to instill in children a sense of deep respect and devotion to the mother. Respect is dear to the mother. Respect is a response to her love, gratitude for her labors. It must naturally sprout out of love, out of attachment of children to their moms. Everyone in the family should be aware of this, learn this and teach everyone to this, especially the young ones. It is not only edification that should be used but personal examples of the elders. That's why it is not accidental that being asked how the parents should educate their children correctly the famous Chuvash ethno-pedagogue G. Volkov gave a brief answer "through love" bearing in mind parental love for children and children's love for parents. The children who love and respect their parents are expected to love and respect their spouses and children in mature lives.

It should be noted that the Chuvash mothers, after giving birth to children sacrifice a lot for the sake of their children. Most of them consider this a must because their mothers behaved that way and taught them to behave the way their ancestors did a long before. There is a folk saying allegedly justifying their sacrificing behavior which reads: Çamrăklăh văhătlăh, văl kilet te kayat'. Malashlăh achasenche, věsemshěn purănmalla - Youth life period is short. Further on we (i.e. Chuvash mothers) must live in the name of children. Chuvash mothers are of the opinion that youth comes and goes, not allowing any transitional stages between the birth of children and further family life. This is especially noticeable in rural families. In urban families Chuvash women-mothers even after 40-45 years stay fit and attractive. They don't want to have many children. They usually have one or two children at most. They hate hard work. Married Chuvash women in rural areas after 30 years cease to take care of their appearance. They are aging rapidly. They explain this by the specific conditions of rural life and the consequences of hard physical labor, although their physical activity and health often exceed the health status of urban women. This, in our opinion, is due to the fact that rural Chuvash women themselves put up with this state of affairs. They consider their relationships with their husbands and those with their relatives stable, their own marriage strong, indissoluble. In spite of difficult rural life, daily household chores, malnourishment at times to save money for building a village house of their own, Chuvash mothers remain loyal to their husbands, love their children. They try to avoid any possible family destructing conflicts, thus sacrificing themselves altogether for family values which they inherited from their ancestors. Chuvash mothers believe that what they do and the way they behave in the family will be rewarding to the benefit of all members of the family whatever the cost might be. They firmly believe that their selflessness, fidelity to marital ties, the willingness to sacrifice for the sake of children, for the sake of their future, impeccable self-discipline and devotion to children and her husband further strengthens the family. 
This pattern of behavior is still preserved in many Chuvash families today, where the cult of grandparents, parents and children is scrupulously observed. Faith in the family rises in such families to the level of not only firm convictions, but a kind of religion. The solidarity of the Chuvash family, the presence of a national model of the family in it, admiration for parents and elders, labor traditions allow children to be attracted to the common problems and concerns of the whole family from an early age. From an early age, a Chuvash child, following the example of his parents, prepares himself for a life that might be not easy at all. There is a well-known Chuvash saying proving that a Chuvash boy from early childhood learns to acquire men's labor skills working together with his father. It reads Viççěri acha hărah uripe suhara tărat' - A three-year-old Chuvash boy's foot is in a plow furrow. Anyhow that doesn't mean that allegedly too much harsh male parents make their boys do a very hard work so that it might do harm to the latter's health. The main idea here is that the boy watches his father work and learns basic labor skills. He is taught not only to work, but to follow wholeheartedly his mother's and father's behests, to be ready to withstand all possible hardships in life and to overcome them. That's why in his adulthood he does it not out of fear of parents' punishment, but out of devotion to his no younger already parents and the feeling of a very deep respect for them.

Judging by what is said about the Chuvash family parenting above one can't but notice that father and mother represent opposites which dissolve in the process of common parenting, for these opposites work for one common cause, i.e. parenting and educating their common children which are furthering their dynasty. Fathers are usually strict, demanding, caring, responsible persons. Mothers are usually kind, loving and affectionate, intelligent, sensible, caring. Anyhow, nowadays most parents seem to overprotect their children. This is fairly expressed in the Chuvash saying Epir kurnine achasen kurmalla an pultăr - The things that we had to endure and have endured on our shoulders may never get our children. Anyhow some elderly Chuvash people think overprotection and overcare may interfere with the traditional Chuvash family parenting and education. While the educationists argue on this problem the majority of Chuvash family parents try to balance between "traditionalists" and "overprotectionists". Adherence to family values, traditions, worldview of the Chuvash most often allows the parents to find a way out of any difficult situation. The criterion of correctness of their system of parenting and education is accounted for by the fact that the children in their adulthood find their places in their lives preserving herewith the best family parenting and education traditions, i.e. love and respect for their parents. The children are proud of their parents, and the parents in their turn are proud of their children.

The attitude of the Chuvash to the role of father and mother in raising children is quite definitely expressed in the saying Chun parakan atte-anne mar, ăs parakan atte-anne - Parents are not those who gave the soul, but those who gave the mind.

It is always much easier for a mother to raise children if the father also takes an active part in this process. In the course of emancipation the Chuvash woman-mother received and enjoys equality in all spheres life. On the one hand, such a phenomenon can only be welcomed when a mother-woman is a tireless production worker, statesman, social activist, citizen. On the other hand, the emancipation of women leads to that the mother has less time to devote to her children, and this will certainly affect their upbringing. At the same time the Chuvash woman-mother tries to raise worthy children - the successors of the family kinship, very often forgetting about herself, never complaining about her fate.

The role of the father in the parenting and educational process is very high. Both paternal feelings and spiritual kinship arise in fathers gradually. The children have a strong influence on the formation of many positive qualities in the father, including the feeling of a father. The pedagogical role of the father is considered in terms of both authority and in terms of his practical activities in educating his children. The father's work, his public image, the level of culture, the performance of household duties, tireless educational activities, attitude towards the mother, towards other people, his lifestyle in general - this is not a complete list of the components of his true authority for which he is sure to deserve love and respect of his children not alone his spouse. It is a traditional rule in the Chuvash family when the father poses himself as a friend of his children. He tries to communicate with his children as if he were their friend. It is not accidental that the well-known Soviet educationist A.S. Makarenko remarked on this occasion: "Father and son can be friends, they must be friends. But the father still remains the father, and the son remains the son, that is, the boy who needs to be brought up and who is raised by the father, who thereby acquires some characteristics that are additional to his position as a friend "(Makarenko, 1984, 206).

For every father respect of his children is a test of all his qualities, an assessment of all his activities, and often that of his whole life. Respect of children for their fathers has always been viewed as a sign of the strength and power of the people. Father's example in the family atmosphere of trust and mutual respect were the main means of raising children in the spirit of love and respect for parents, family values, further on 
spreading for the community and the country they live in. Unfortunately, we have to admit that nowadays some fathers more often than not do not even know how their behavior affects the formation of the child's personality. In is quite comprehensible as modern pace of life is challenging so that the parents and children are prone to get alienated. Anyhow we do not think that contemporary technological innovations in society should impact the minds of fathers and children to such an extent that they can get alienated. That's why it is so much important as never before preserve the traditions of family parenting and education through creating special coaching centers for younger parents to remember the fundamentals of folk pedagogy which rests on folk wisdom being represented by fairy tales, songs, proverbs and sayings. Apart of indulging into theoretization on principles of family parenting and education only it is advisable that young parents should acquire practical skills of applying fairy tales, songs, proverbs and sayings in upbringing their children. It is noted in folk pedagogy that the parenting role of the father is mainly based on two principles, i.e. moral and material principals. Following the moral principle of parenting the father is of the opinion that he has the moral authority to order and demand and the commitment to defend his family. For example, he can prohibit his children to have long night walks, or he can demand that children behave so that as to preserve the family honor. The material principle presupposes the father's commitment to maintaining his family financially.

The parenting and educational activity of the Chuvash parents is to establish relationships between the parents themselves, between the parents and the children, the family members and the people around them. If the father protects and raises the prestige of the mother, then this has a positive effect not only on the authority of the mother, but also on the father himself. For parents, children always remain children. As adults who already have their own families, matured children can't but obey their parents and follow their orders and actions because for them there is no one above their parents and nothing above their authority.

When the Chuvash children in adulthood create their own families they seem to get alienated from their parents. At the same time newly formed families try to keep closer to their parents. There is a need to share plans, joys, to follow any good advice from the elderly parents. Very often mothers-in-law interfering with the plans of the family of their matured children may break up young, potentially viable families. The parents are often biased and suspicious. It seems to them that "parental instinct", "mother's heart" speaks in them, but in fact they experience sharp secret jealousy, fear of loneliness. They desire to retain power over their child into whom so much energy, hopes and love have been invested. Rough intervention of parents often hinders the harmonious development of interpersonal relations between young spouses, brings about conflicts and divorce. However, if the parents have lived their lives well together, then the young have something to learn from them, and they can safely rely on their parents' experience.

The most active educators of spouses in a newly formed Chuvash family are grandparents. The children born into a newly formed family have four grandparents, i.e. two at the father's side and two more at the mother's side. The grandparents on the father's side are named asatte - grandfather and asanne grandmother. The grandparents on the mother's side are named kukasey - grandfather and kukamai grandmother. The role of grandparents in folk pedagogy is determined by that the old people with rich experience are the best educators of the younger generation, i.e. their grandchildren. It is stated in folk pedagogy Vată çynna itles pulat', çamrăkkine vĕrentes pulat' - The old one must be listened to, and the young one must be taught. This statement defines the relationship between the old and young generations. There was an understanding among the Chuvash people of the connection between the past and the present, between the old and the young that is expressed in the saying Vattisene yuratmanni věttisene te yuratmast - Who does not love old people does not like children.

Grandparents' blessing of the young spouses at the wedding ceremony is considered a guideline for their future life together, i.e. a kind of recipe for a happy family.

Academician G. Volkov, the founder of the Chuvash ethno-pedagogy as a science, notes that "the cult of ancestors was very widespread among the Chuvash. As a matter of fact it has universal roots. It is believed that the cult of veneration for the elderly arose due to the fact that primitive man could not explain the phenomenon of death. He believed that a deceased person would need everything that had surrounded him during his life. Subsequently, when men were even at a sufficiently high level of spiritual culture, they didn't give up the idea of the cult of their predecessors, moreover, from religious it became moral and pedagogical. A particularly respectful attitude towards the old has always been a significant feature of the Chuvash, i.e. the religious cult of dead ancestors, as a rule, was combined with the pedagogical cult of living grandfathers and great-grandfathers. The cult of ancestors was constantly and systematically supported by the deliberate exaggeration of the role of the old and that of their experience for the life of the young. The presence of an element of consciousness in this exaggeration more and more displaced the religious and superstitious from 
the cult of ancestors and more and more expanded and strengthened the positions of the pedagogical component in the cult. At the same time, the expansion of the positions of the pedagogical component proceeded not only along the line of all-round strengthening of the authority of the old, but also in terms of respect for the history of the people. Thus, respect for the old, brought to a cult, also supported interest in the history of their people. This established a connection between the younger generation and the outgoing generation, fostering and thereby forming in them a sense of blood connection with their native people, with its past, present and future "( Volkov, 1997, p. 401].

It has been a good tradition among the Chuvash since long that relatives also take part in the upbringing of young spouses. They see to it that the young spouses keep the ancestral traditions and good family customs. The relatives help young people not only morally, but even financially as well especially when the latter get into difficult life situations.

Special attention should be paid to the educator of young Chuvash spouses named hăimatlăh - best man, i. e. groom's best friend who fulfills the parental functions for newlyweds along with their biological parents.

Ella Sokolnikova in her book "Ethnopedagogy of the Chuvash family" emphasizes that "the terms hăimatlăh ashshĕ and hăimatlăh amăshě originally meant "his father who raised him" and "his mother who raised him." The bride had to name hăimatlăh and his wife as parents, and all her life she, like her husband, honored them as her own biological parents "(Sokolnikova, 1997, p. 304).

Currently all Chuvash weddings are still held in compliance with folk traditions and customs. As Academician G.N. Volkov emphasizes that the role of hăimatlăh is very great at such weddings. He writes: "The person the closest to the groom is chosen a hăimatlăh, and this closeness was often measured not so much by family ties as by the degree of a person's involvement in the groom's upbringing <...> After the wedding, hăimatlăh and his family become close relatives of the newlyweds. Hăimatlăh gives them gifts and provides all kinds of assistance to the new family. Hăimatlăhs at weddings are not only dignitaries as the roots of their special position at the weddings have a deeper meaning. They deserved to be named hăimatlăh by raising the groom. The wedding party is a kind of platform on which the educational activities of the hăimatlăh are summed up. Hăimatlăh's family supports the spouses throughout their lives. Hăimatlăh gives gifts to the young in connection with the birth of a newborn "(Volkov, 1997, p. 405). Thus a continuous pedagogical interdependence is established which is supported by material assistance and moral support.

After the Christianization of the Chuvash the function of hăimatlăh was fully assumed by the recipients, godfathers and godmothers. Ella Sokol'nikova notes the role of godparents in the following way: "The Chuvash who once experienced public custody of children made godparents as responsible in raising children as the ancient hăimatlăhs. The religious form of the godparents could not destroy the healthy pedagogical principle contained in the activities of the hăimatlăhs. Moreover, hăimatlăh in the central regions of Chuvashia, where Christianization was carried out less intensively, retained its strong pedagogical positions, secular form and the name pysăk atte (anne) - big father (mother)" (Sokolnikova, 1997, p. 307).

Currently, the role of godparents in the formation of a young married couple is very great. Observing age-old traditions and customs, the godparents, like the parents of the newlyweds, bless them expressing their best wishes for a happy family life.

Academician G. Volkov emphasizing the role of hăimatlăh writes that "the position of hăimatlăh as well as the role of godparents testifies to the fact that the Chuvash people still have an extremely high moral weight of the educator. Hăimatlăh at a wedding ceremony which is perceived as the final process of raising young people, is especially honorable, even more honorable than the fathers of newlyweds. The father who gave birth was only a father, whereas hăimatlăh who raised the groom was a great father. Hăimatlăh was a kind of representative of the community in the family"(Volkov, 1997, p. 405).

It is common knowledge that public opinion is an effective pedagogical tool. It is supported by neighbors, authoritative residents. The role of neighbors in raising newlyweds and establishing harmonious interpersonal relationships in the family is also important. Honesty towards neighbors has always been preached to children by their parents, since spouses always have to reckon with the opinion of neighbors.

There are many folk songs, proverbs and sayings about good neighbors who rejoice about newlyweds who settle down to live in neighborhood, e.g. Kÿrshĕ-arshă ayakri tăvantan paha - Neighbors are much dearer than distant relatives, Puskil layăh pulsassăn çuk purnăç ta palărmast', puskil usal pulsassăn pur purnăç ta salanat' - With good neighbors poverty is not noticeable, with bad neighbors prosperity goes to dust), Kÿrshĕsĕr kil-çurt çavăraimăn - You cannot build a house without neighbors (Ashmarin, 1928-1950, p. 164). The young people at the wedding are usually blessed with the following words: Kilti çup-çapa urama ilse an 
tuhăr, uramri çup-çapa kile ilse an kĕrĕr - Do not wash dirty linen in public, and do not bring it back. The moral admonitions with which the parents specifically addressed the children also contain the following sayings, i.e. Kÿrshĕ mĕn kalat' - What a neighbor will say, Kÿrshe an kÿrenter - Do not hurt your neighbors (Ashmarin, 1928-1950, p. 315). The above mentioned proverbs and sayings are still in active use as a verbalized pedagogical tool in parenting and educating children and youngsters in Chuvash schools.

Thus, it should be noted that the role of the father's house is great thanks to the mother's "lullaby" care and the father's "laconic" love for their children. It is in father's house that the children get a schooling of spiritual and moral education. It is in the family that the children learn the fundamentals of harmonization of interpersonal relations from early childhood to adulthood and a family life start-up. They learn to get on with their parents, the elderly, the relatives, other children, the neighbors and the members of the community they belong to. They learn to value contacts and connections. They come to understand that it is hard to live in the world without connections with relatives because if one has no family or relatives, then there is nothing to lean against, there is no one to apply for advice. There is an opinion among the Chuvash people that without contact with relatives, parents, brothers and sisters, as well as with the members of the community one lives in, one becomes as helpless as a "lost sheep". Maintaining warm family ties helps to overcome family troubles, fosters deep family feelings among young people, and helps to harmonize interpersonal relations between spouses in a modern young Chuvash family.

\section{CONCLUSION}

Spiritual and moral education of children is defined as the process of assimilation and appropriation of universal moral values incorporating such concepts as Motherland, family, nature, work, friendship which are formed on ethnic family traditions in the multicultural environment (Pushkin et al., 2015, p. 242). The moral formation of the individual takes place in the unity of moral consciousness, moral thinking, and moral deeds.

The sensitivity of age, the figurative-emotional nature of thinking, the desire to imitate elders contribute to the assimilation of norms of behavior by children, the conscious manifestation of such moral qualities as sympathy, responsiveness, mercy, compassion, generosity, friendship.

The sources and means of moral education based on the traditional values of the Chuvash family are folklore comprising fairy tales, proverbs, sayings, songs, ditties, round dances, outdoor and competitive games, labor traditions including folk help, work for the good of the family, and traditional holidays and folk crafts.

The educational process with children should be aimed at assimilating those family values that have developed and have passed the test of time, have allowed them to remain Chuvash and harmoniously fit into a multicultural context. These values are as following:

- Honor of the family and clan, which has been considered the basis of family life since ancient times;

- Well-being of a family with many children;

- Emphasized respect for parents and elders, unconditional veneration for them;

- Desire to live by one's own labor, since a person is valued primarily by his labor;

- Attachment to one's home;

- Deep loyalty to friendship, kinship and neighborhood, which allows even today not to get lost in life, to feel being supported and experience support of loved ones;

- Hospitality as a family value.

The moral potential of the values of the traditional culture of upbringing in the Chuvash family consists in unconditional respect for parents and elders and the strength of family ties, hard work and the desire to live by one's own labor, hospitality and deep fidelity to friendship, kinship, neighborhood. The moral potential contributes to the establishment of harmony in relations with peers of different nationalities, upbringing feelings of respect and interest for other peoples, their customs, traditions and beliefs. It contributes also to the development of interethnic and ethno-cultural tolerance. An effective means of establishing interethnic relations on the basis of understanding and accepting moral values as universal and significant for everyone, regardless of ethnicity, is the ethno-pedagogical dialogue of traditional family parenting and education among the Chuvash. This dialogue allows all peoples to live in peace and harmony. 


\section{REFERENCE LIST}

Ashmarin, N.I. (1928-1950). Dictionary of the Chuvash language, 17 (2).

Chuvash fairy tales: collection (1937).

Egorov, D.E. (1999). Women-mothers of the Chuvash land.

Makarenko, A.S. (1984). Pedagogical works, 8 (4).

Ozhegov, S.I. (1997). Dictionary of the Russian language.

Pushkin A. A., Tenyakova E. A. (2015). Value Concepts in Modern Paradigm of Spiritual and Moral Education: Lingua-pedagogical Aspect. Modern Problems of Science and Education. No. 2-2

Pushkina, K.V. (2002). Fundamentals of a harmonious marriage. Family in Russia, 2.

Pushkina, K.V. (2002). The role of educators in the harmonization of interpersonal relations between spouses in a modern young family. Family in Russia, 1.

Pushkina, K.V., Nikolaeva, N.V. (2017). Traditions of education in a modern Chuvash family. Problems of modern pedagogical education, 6 (55).

Romanov, N.R. (2012). Chuvash proverbs, sayings and riddles: collection.

Sokolnikova, E. I. (1997). Ethnopedagogy of the Chuvash family.

Volkov, G.N. (1958). Chuvash folk pedagogy: essays.

Volkov, G.N. (2004). Chuvash ethnopedagogy, 1.

Yakovlev, I. Ya. (1997). My life: memoirs. 